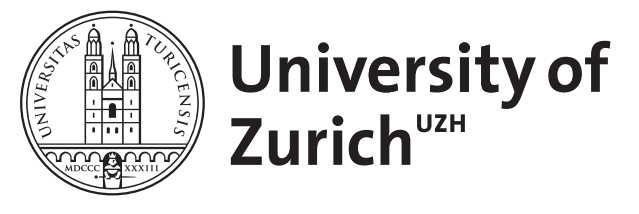

\title{
Dialect dictionaries
}

Barbato, M

\begin{abstract}
Due to historical conditions, and in contrast to other Romance areas, a common standard language appears quite late in Italy. In the 16th century Tuscan definitively establishes itself as a literary language, but it is only after the political unification of the country in the second half of the 19th century that the foundations are laid for its linguistic unification. This has led to a multiform linguistic history and the persistence of an uncommonly high level of diatopic variation in the Italo-Romance area. Dialect dictionaries bear witness to these historical events and to the vitality which dialects still have in modern Italy, despite the increasing pressure of the standard language. The present article aims to describe briefly the various typologies of dialect dictionaries, focusing on the way they select and organize the linguistic material, the targets they set themselves, and the results they achieve
\end{abstract}

DOI: https://doi.org/10.1093/ijl/17.4.429

Posted at the Zurich Open Repository and Archive, University of Zurich

ZORA URL: https://doi.org/10.5167/uzh-155591

Journal Article

Published Version

Originally published at:

Barbato, M (2004). Dialect dictionaries. International Journal of Lexicography, 17(4):429-439.

DOI: https://doi.org/10.1093/ijl/17.4.429 


\title{
DIALECT DICTIONARIES ${ }^{1}$
}

Marcello Barbato: Universität Zürich Romanisches Seminar (barbato@unina.it) and Alberto Varvaro: Università di Napoli Dipartimento di Filologia moderna (varvaro@unina.it)

\begin{abstract}
Due to historical conditions, and in contrast to other Romance areas, a common standard language appears quite late in Italy. In the 16th century Tuscan definitively establishes itself as a literary language, but it is only after the political unification of the country in the second half of the 19th century that the foundations are laid for its linguistic unification. This has led to a multiform linguistic history and the persistence of an uncommonly high level of diatopic variation in the Italo-Romance area. Dialect dictionaries bear witness to these historical events and to the vitality which dialects still have in modern Italy, despite the increasing pressure of the standard language. The present article aims to describe briefly the various typologies of dialect dictionaries, focusing on the way they select and organize the linguistic material, the targets they set themselves, and the results they achieve.
\end{abstract}

\section{Preliminary Remarks}

Within the complex linguistic framework of modern day Italy, the dialect dictionary may have a wide range of quite different justifications and purposes. Alongside works existing for purely scientific ends (there are many such works, and of high quality, too), the dialect dictionary may aim to help the dialectspeaker learn Italian, or to demonstrate the richness and nobility of the dialect, or to praise its remote origins, and so on.

Indeed, the oldest dialect dictionaries aimed to demonstrate how dialects could be compared to Latin and as such were as noble as the Tuscan dialect. These works tend to treat the dialect as a literary language, and often completely neglect everyday vocabulary. Later on, in the 1800s, the aim of helping the dialect-speaking student learn Italian seems to prevail. In the meantime scientific dialectology came into being, and the lexicographer of dialects gradually diverted his attention away from the dialects of the cities and of the upper classes towards the language of artisans and later, of the rural classes. In the closing decades of the century, as people felt more pride in stressing the roots of local culture, the contribution of the dictionary is apparent in various 
ways, as a source of accurate or presumed etymology or of inventories of the names of objects or practices threatened with extinction.

In Italy the production of dialect dictionaries continues to flourish. In part this is due to the interest shown by local communities: such works are often edited and subsidised by local councils or other regional authorities. These are praiseworthy initiatives, but do little to ensure the circulation of such books as they are not usually on sale to the general public. However, the value of these works ranges widely - from the extremely valuable to the virtually useless, as far as the scholar is concerned; this may be due to dictionaries being compiled without clear criteria or because they are riddled with serious defects or faults. Nonetheless the enthusiasm of the compilers has to be recognized and it must be said that often even the most amateurish efforts provide interesting data. It would be a mistake to judge these works solely in terms of scientific methodology. The majority of such dictionaries can be traced through the bibliography in the Lessico Etimologico Italiano (LEI).

\section{Premise}

The present article will be concerned with lexicographical works produced from 1980 to the present day (for the preceding period, see Marmo, Martinelli and Mendia 1981) and focus on dialect varieties used in Italy from 1525 onwards (the date when modern Italian is conventionally said to have come into being, and consequently when a dialect can be distinguished as a variety subordinate to a standard). ${ }^{2}$ The allogenous varieties spoken within the Italian borders are excluded (Pellegrini 1977), as are Sardinian, Ladin and Friulian - due to their structural differences compared to Italian and the more or less marked nature of their sociolinguistic status compared with the standard language. Among the Italo-Romance varieties used outside Italy, the Swiss Lombard and Istrian dialects (which have Italian as their roof-language) are included, but not Corsican. Firstly, marginal typologies (special and bilingual dictionaries) are dealt with, then the standard case of the homogloss dictionary (i.e. a dialect dictionary with the glosses in the corresponding standard language, cfr. Marello 1989), which will be further differentiated according to how widespread the variety in question may be.

\section{Special dictionaries}

The sample volume of the Vocabolario delle parlate liguri (VPL, see below, section 5.3) is a special dictionary dedicated to Ligurian ornithological terms (Petracco Sicardi 1982), based on material gathered in the field, supplemented with material from written sources from the 19th and 20th centuries; it includes 
illustrations. It is ordered alphabetically, but may be consulted onomasiologically by means of the Italian-Ligurian index. The entries conclude with a brief comment on the area over which the word is used, and on its phonetic evolution. Sella (1992) is an excellent example of a dictionary of plant names in a Piedmontese dialect, based on material collected in the field, and on written sources from the Middle Ages onwards. The headwords are the scientific Latin names in alphabetical order. There is a wealth of information on traditional uses of plants and the beliefs attached to these. The work has indexes of Italian and dialect names. Sella (1994) provides the corresponding work for popular zoonomy. Here, however, items are ordered at first by their class (mammals, etc.) and then alphabetically by their Italian denomination. Special dictionaries concerning particular technologies and referring to the past also exist, although in this case the language variety in question is regional Italian rather than dialect (Concina 1988).

\section{Bilingual dictionaries}

The lexicography of the period in question (with a few precursors in the previous decade) shows a tendency which is worthy of note. In dialect dictionaries a significant Italian-dialect section appears with increasing frequency. This tendency develops into actual bilingual dictionaries as such, or even Italian-dialect dictionaries (cfr. Salzano 1980; Antonini 1983; Capacchi 1992; Magri 1995; Brero 1997; Toso 1998; Amato and Pardo 2001; Circolo Filologico Milanese 2001). These works are normally of low quality but of wide circulation; they point to a real interest in dialect, but also to the transformation that the repertory of the varieties has undergone. The more a dialect loses ground to Italian, until it is reduced to a second language, the more the dictionary becomes a necessary instrument, to learn it or at least to keep it alive. Thus the situation is reversed completely, as compared to that found in postunification Italy, which was a prolific period for the production of dialect dictionaries, aiming to italianize dialect speakers, with their native variety as a starting point.

\section{The homogloss dictionary}

\section{I. The writer's dictionary}

Goldoni's project for a dictionary 'for use with his plays' was realized by Folena (1993). This work, begun in the Fifties and directed by one of the principal Italian philologists of the second half of the 1900's, is based on the systematic analysis of the whole of the Venetian playwright's works in dialect. This provides an invaluable instrument for readers of Goldoni, for scholars of literature, and of Venetian dialectology. 


\subsection{Dictionaries of a single locality or microarea}

Dictionaries of this type are by far the most common. As far as their authors are concerned, they may be divided into three categories: (a) dictionaries produced by academics, or at least authors with a linguistic training, (b) dictionaries produced by a collaboration between professionals and amateurs, and (c) dictionaries by amateurs, often teachers, dialect poets or aficionados of local history and culture. From the viewpoint of the user, dictionaries of type (a) or (b) are principally aimed at the scientific community, but pay progressively more attention to local communities; dictionaries of type (c) are normally compiled to serve the local communities, but it is not unusual for them to be written out of purely scientific intentions. Local rivalry may also give rise to a dialect dictionary (Bucci 1982), or the nobler desire to heal the wound of a traumatic event, like the 1980 earthquake in Irpinia (De Blasi 1991). The declared targets are frequently the younger generations, or lovers of literature in dialect.

Of the type (a) dictionaries, the following are worthy of note: Bruschi (1980), Pagani (1983, 1990, 1997), Magenta (1984), Consolino (1986), Doria (1987), Tropea (1988), Tomasini (1989), Greco (1990), Mattesini and Uguccioni (1992), Mancarella (1994). As for the type (b) dictionaries, supervision by academics ranges from the organization of the inquiry (Giacomelli, Gori and Lucarelli 1984; Fortina et al. 1992; Cabella 1999), to more concrete collaboration (Manzini and Rocchi 1995; Antonioli and Bracchi 1995; Tempesta and Valente 1999), to a more or less thorough lexicographical revision (Aneggi and Rizzolatti 1984; Beggio 1995; Castellani 1999; Salvadori 1999). The majority of dictionaries pertaining to a single area - and thus of dialect dictionaries tout court - are of type (c). In this category, too, excellent publications are to be found (Tomasi 1983; Domini et al. 1985; Massera 1985; Bondardo 1986; Pellizzer and Pellizzer 1992; Germani 1993; Granatiero 1993), but more frequently the works produced are lacking from the point of view of methodology, if not totally unreliable. The efforts of their authors may nevertheless be appreciated because - as lexicologists and dialectologists well know - the worst of these dictionaries may still be of some scientific use. Moreover such works should not be judged according to standards of academic correctness, but rather seen for their true nature - as instruments of transmission of knowledge, both linguistic and non-linguistic, which is under threat of extinction (hence the tendency to blur distinctions between dictionary and encyclopedia). The claim of the authenticity of the dialect against prevailing conformity, the intention of saving traditional culture along with dialect from the threat of modernization constitute the Leitmotiv of the prefaces of these dictionaries (but these notions are not entirely absent from more scientific works either). A sign of the times is that defence of dialect often appears in a conservative light and promotes a separatist identity, in complete contrast to the spirit of the Seventies, when the alternative nature of a popular variety was 
emphasised, as well as the juxtaposition between a hegemonous culture and a subordinate culture.

5.2.1. Collection and selection of materials In most cases the dictionary is solely the result of the dialect-speaking author's native competence, helped by friends and relations, if by anyone at all. In some cases it is the result of a rudimentary inquiry normally based on a dictionary of Italian usage. In more sophisticated cases the research is carried out by means of a purposely-created questionnaire or based on one prepared for a linguistic atlas. Almost all the dictionaries intentionally exclude not only italianisms but also dialect words which diverge only formally from their Italian equivalents. In some cases the authors intentionally present an archaic stage of the dialect or devote more space and attention to vocabulary relating to traditional culture or to particular technologies. Many works integrate oral material with material from often undeclared written sources. Some works also include historic sources, thus deviating from the general synchronic nature of these dictionaries (Tomasi 1983; Domini et al. 1985; Bondardo 1986). As regards dialects with a literary tradition, such as the Roman and Neapolitan dialects, the need for a historical dictionary cannot be satisfied by works without any concern for the most basic of philological procedures (D’Ascoli 1993; Ravaro 1994).

5.2.2. Macrostructure The only onomasiological dictionary is by Pagani (1983, 1990, 1997), organised as a linguistic atlas, with broad fields of reference (the human body, space and time, vegetation and produce from the land); however, it does include an alphabetical index of dialect entries. Some dictionary compilers seem undecided between alphabetical and semantic order. Baldoni et al. (1987) list under the entry cašer 'cheese-maker' all the terminology for cheese-making, with terms which are missing in the word list. Corbatto (1995) inserts among dialect entries the Italian headword uccelli 'birds', with a list of 73 local denominations. The composition of the word list also reflects the lack of distinction between abstract lexical units and their realisations in discourse. Sometimes single verb forms such as xe 'he/she/it is' (Corbatto 1995), ànno 'they have' (Vincelli 1991) may be listed as headwords, as may also be phrases such as discete grusse 'thumb', affurteché i mmàneche 'roll up your shirtsleeves', and whole clauses such as làsseme sté 'leave me alone' and scugnate 'a zappe (s'é) 'the hoe has lost its wedge' (Piazzolla 1982). Proper names are frequently included as headwords: not only Christian names glossed by Italian equivalents (as occurs in bilingual dictionaries, too), but also names with a single referent (place names, historical personalities, family names and nicknames) and with a gloss which is obviously encyclopedic and not linguistic.

As mentioned above (section 4) the dictionaries often contain Italian-dialect appendices, which may even be as long as the dialect-Italian section. Some works (Magenta 1984; Antonioli and Bracchi 1995; Manzini and Rocchi 1995) have an Italian-dialect index to aid onomasiological research. But the semantic 
appendix may also appeal to dialect poets 'to express concepts which are already clear, yet ill-defined' (Zaccagnini 1992: 197). Salzano (1980) contains elements of metre and a rhyming dictionary. Type (a) or (b) dictionaries often contain notes of historical grammar, which may even reach the dimensions of an article (Tropea 1988; Bracchi in Bianchini 1994; Mancarella 1994; Antonioli and Bracchi 1995). Tomasini (1989) and Pagani (1990,1997) have an index of etyma. Good grammatical notes have also been written by non-professionals (Diana 1995). Often the grammatical part is limited to morphological tables, which are nonetheless useful. Many dictionaries contain onomastic appendices: lists of place names, lists of local equivalents of Italian christian names, and lists of nicknames, which traditionally substitute family surnames. Others, as indicated above, include this material directly within the word list. Many works attach texts in dialect: tales, poems, rhymes and proverbs. Lists of comparisons are also frequent, as well as idiomatic expressions (elements of a language which are acquired late and easily lost). Illustrations are less frequent, and not particularly useful in many cases.

5.2.3. Microstructure The majority of dictionaries make use of a modified Italian graphic system to render dialect sounds. The results are usually effective even though the criteria for transcription are not always clearly illustrated. Semiphonetic transcriptions (normally based on one of the variants of the phonetic alphabet used by Romance philologists) follow in order of frequency. Often indicators or markers of style (familiar, vulgar, etc.), and sometimes even grammatical markers (noun, verb, etc.) are absent. Generally information regarding the valencies of verbs is insufficient, with more frequent information on endings (verbal and nominal). The average level improves for definitions and phraseology.

Some works make reference to dictionaries for the surrounding area or to etymological dictionaries (Greco 1990), or make geolinguistic and historicaletymological comments (Tomasini 1989; Antonioli and Bracchi 1995; Doria 1987; Manzini and Rocchi 1995; Tempesta and Valente 1999). From this point of view even some non-professional authors achieve a good standard (Bondardo 1986; Pellizzer and Pellizzer 1992). However, more frequently this enthusiasm for historical and linguistic information proves to be counterproductive, as the most unprepared authors sacrifice the more strictly lexicographical aspects to absurd etymological debate. Many dictionaries make it clear from their title that their sole raison d'être is a generally unfounded etymological interest. Several research-oriented works have an undisguised ethnographic interest (Bianchini 1994; Antonioli and Bracchi 1995) which is reflected in the encyclopedic nature of the glosses. Many type (c) dictionaries contain a wealth of information on traditional culture. It is not rare to find entries containing anecdotes or local history. For example in Castellani (1999), under cunsigliér 'councillor', there follows a list of the councillors elected from 1848 onwards to represent the suburb of Cascinagrossa on the Alessandria local Council. 


\subsection{Regional dictionaries}

In recent times dictionaries for various regions have been published, continued or completed: the Vocabolario dei dialetti della Svizzera italiana (VSI), founded in 1907, with a first publication in 1952, is still in progress; the Vocabolario siciliano (VS), published (after a sample issue in 1961) from 1977 until 2002; the VPL completed in its entirety between 1985 and 1992 (the different time scales also reflect the diverse ranges and ambitions of the works). Bigalke (1980) should also be mentioned, which is a work of a more modest dimension.

\subsubsection{Collection and selection of materials The VSI is based on material} collected in the first four decades of the 20th century, through phonetic inquiries, and a questionnaire filled in by the informants themselves. In the VS only the latter method is used although it is currently rather out of fashion. The VPL is also based on a questionnaire but the methods of data collection are not described in any detail. Bigalke (1980) is based on personal collections, on previous studies and on dialect literature of the 1900s. The VS integrates the newly collected material with written sources from the 17 th century onwards, to such an extent that it must be considered a truly historical dictionary of Sicilian. The VSI conducts a systematic survey of all written sources, including medieval sources, both in the vernacular and in Latin.

\subsubsection{Macrostructure Regional dictionaries present particular problems} regarding the ordering of the material, in that they have to account for the multiplicity of meanings and also variations of form. In the VSI phonetic variants of a lexeme are included under a single headword, but also appear in alphabetical order with a reference to the corresponding entry. The VPL also opts for this system, but unlike in the sample volume (cf. section 3 ), the variants of a headword do not appear in alphabetical order; the index of forms only partially compensates for this, since it is 'necessarily selective for reasons of space' (vol. IV, p. 69). On the other hand, the VS does not enter phonetic variants together under a single headword (or at least not systematically). So, for 'bianco' there are three entries, bbiancu, iancu and viancu. Thus also Bigalke (1980), who has 14 entries for 'lingua'. It is clear that this second option inevitably produces repetitions, but has the advantage of allowing for a more transparent relationship between form and meaning.

The VSI has an index with all the cited forms listed for each locality, and an index of etyma; in addition, in the first three volumes there is a topic index (which also functions as an onomasiological index) and an index of linguistic phenomena, which lays the basis for a historical grammar of the dialect varieties. Bigalke (1980) has a long, but somewhat muddled, linguistic introduction. The VPL has an Italian-Ligurian index. The VS is due to publish a volume containing an Italian-Sicilian index and a reverse lexicon.

5.3.3. Microstructure In VSI the use of a phonetic transcription alongside the modified Italian spelling corresponded to the different sources of the material 
(phonetic inquiry or answers to questionnaires) and to the different aims (a basis for phonetic study or simply lexical information). In the VPL, too, the forms are given both with modified and phonetic spelling, but here the double transcription does not seem very useful: in fact the phonetic form is only rarely narrower than the non-phonetic form, and it is difficult within one entry to refer from one to the other. The VSI itself, from volume IV onwards, has reduced the phonetic part and abolished the system of double transcription of an entry in favour of a more efficient modified spelling. The VS makes use of a workable semiphonetic transcription, Bigalke (1980) uses phonetic transcription.

The entries in the VSI contain an exhaustive historical-etymological commentary. In contrast to the sample volume (cf. section 3) in the VPL there is only occasional commentary. Bigalke (1980) limits himself to an indication of the etymon and some references to other dictionaries. In the series of national Swiss dictionaries, the VSI was expressely intended as an 'encyclopedia of the life of the people of the Canton Ticino and of the Italian valleys of the Canton Grigioni' (vol. I, p. XIV). As a result it contains a wealth of historical and ethnographic information, with very valuable illustrations. The entry for alp 'alp', covering 30 pages, is a good example, with barely one page given over to lexicography and etymology. The editors themselves later realised the risks of such an endeavor (vol. III, p. 9) and tried to limit the encyclopedic documentation 'to technical and ergological [i.e. relating to work implements] information indispensable to the understanding of the terms, and their cultural and economic importance'.

\subsection{The pan-dialectal dictionary}

Cortelazzo and Marcato $(1992,1998)$ provide a selection of Italo-Romance dialect vocabulary, collecting above all lexemes linked to subordinate cultures or to expressiveness, learned words adopted in distorted form in the dialects, or dialect words which have entered into standard Italian. Lexemes, transcribed semi-phonetically, are given a generic location, and a cursory etymological summary, but the source is never quoted. The second edition is visibly larger in terms of number of entries, but unfortunately lacks the useful tools of the first one: an onomasiological index based on the Hallig-Wartburg system, and an etymological index. It is a work which satisfies the interest of the general public, without sacrificing scientific principles. Obviously anyone looking for a complete range of materials, verifiable sources, accurate geographical locations, and an exhaustive discussion of etymological questions should refer to the Lessico etimologico italiano (LEI) edited by Max Pfister (1979 ff.), the definitive record of Italo-Romance vocabulary of all periods.

\section{Conclusion}

From the above it should be clear that contemporary dialect lexicography in Italy appears as a fruitful area of research in terms of the number of studies, the 
range of themes covered and the quality of production. A central role is played by the LEI, a compendium of previous works with a far-reaching lexicographic perspective. Already a fundamental tool for the study of the Italian lexicon and its history, this work is also making Italian dialect lexicography one of the best explored areas in Romance linguistics.

\section{Notes}

1. Alberto Varvaro is the author of paragraphs 1 and 6, Marcello Barbato of paragraphs $2-5$.

2. Clearly this analysis does not attempt to be exhaustive, but to reflect the current production of dialect dictionaries.

\section{References}

\section{A. Dictionaries}

Pfister, M. 1979 ff. Lessico etimologico italiano, Wiesbaden: Reichert, 1979ff. (LEI) Vocabolario della parlate liguri, a cura di G. Petracco Sicardi et al., 4 voll., Genova: Consulta Ligure, 1985-1992. (VPL)

Vocabolario siciliano, fondato da Giovanni Piccitto, 5 voll., Palermo: Centro di studi filologici e linguistici siciliani, 1977-2002. (VS)

Vocabolario dei dialetti della Svizzera italiana, fondato da Carlo Salvioni, Repubblica e Cantone Ticino, 1952 ff. (VSI)

Amato, B. and Pardo, A. 2001. Dizionario napoletano. Milano: Vallardi.

Aneggi, A. and Rizzolatti, P. 1984. Dizionario cembrano. San Michele all'Adige: Museo degli usi e costumi della gente trentina.

Antonini, A. M. 1983. Vocabolario italiano-milanese. Milano: Libreria Meravigli Editrice.

Antonioli, G. and Bracchi, R. 1995. Dizionario etimologico grosino. Grosio: Biblioteca comunale/Museo del costume.

Baldoni, D. et al. 1987. Vocabolario del dialetto di Cavriago. Bologna: Edizioni Analisi.

Beggio, G. 1995. Vocabolario polesano. Vicenza: Neri Pozza.

Bianchini, G. 1994. Vocabolario dei dialetti della Val Tartano. Sondrio: Fondazione Pro Valtellina.

Bigalke, R. 1980. Dizionario dialettale della Basilicata. Heidelberg: Carl Winter Universitätsverlag.

Bondardo, M. 1986. Dizionario etimologico del dialetto veronese. Verona: Centro per la formazione professionale grafica 'San Zeno'.

Brero, C. 1997. Dizionario piemontese. Milano: Vallardi.

Bruschi, R. 1980. Vocabolario del dialetto del territorio di Foligno. Perugia: Università degli Studi.

Bucci, C. 1982. Dizionario etimologico coratino. Cassano Murge: Tipografia Meridionale.

Cabella, M. 1999. Dizionario del dialetto tortonese. Alessandria: Edizioni dell'Orso.

Capacchi, G. 1992. Dizionario Italiano-Parmigiano. 2 voll. Parma: Artegrafica Silva.

Castellani, F. E. 1999. Dizionario del dialetto di Cascinagrossa. Alessandria: Edizioni dell'Orso.

Circolo Filologico Milanese. 2001. Dizionario milanese. Milano: Vallardi.

Concina, E. 1988. Pietre Parole Storia. Glossario della costruzione nelle fonti veneziane (secoli $X V$-XVIII). Venezia: Marsilio. 
Consolino, G. 1986. Vocabolario del dialetto di Vittoria. Pisa: Giardini.

Corbatto, A. 1995. Vocabolario della parlata gradese. Grado: Edizioni della Laguna.

Cortelazzo, M. and Marcato, C. 1992. I dialetti italiani. Dizionario etimologico. (First edition.) Torino: UTET.

Cortelazzo, M. and Marcato, C. 1998. I dialetti italiani. Dizionario etimologico. (Second edition.) Torino, UTET.

D’Ascoli, F. 1993. Nuovo vocabolario dialettale napoletano. Napoli: Gallina.

De Blasi, L. 1991. Dizionario dialettale di San Mango sul Calore (Avellino). Potenza: Il Salice.

Diana, G. 1995. Vocabolario del dialetto di Monte Compatri. Monte Compatri: Edizioni Photo Club Controluce.

Domini, S. et al. 1985. Vocabolario fraseologico del dialetto 'bisiàc'. Bologna: Cappelli.

Doria, M. 1987. Grande dizionario del dialetto triestino (storico etimologico fraseologico). Trieste: Il Meridiano.

Folena, G. (ed.) 1993. Vocabolario del veneziano di Carlo Goldoni. Roma: Istituto dell'Enciclopedia Italiana.

Fortina, P. et al. 1992. Vocabolario del dialetto di Oleggio. Alessandria: Edizioni dell'Orso.

Germani, A. 1993. 'Arrenneme gliu fazzelettone'. Dizionario del dialetto di Colfelice, Arce e Roccadarce. Comune di Colfelice.

Giacomelli, G., Gori, L. and Lucarelli, S. 1984. Vocabolario pistoiese. Pistoia: Società Pistoiese di Storia Patria.

Granatiero, F. 1993. Dizionario del dialetto di Mattinata-Monte Sant'Angelo. Amministrazione comunale di Monte Sant'Angelo.

Greco, M. T. 1990. Dizionario dei dialetti di Picerno e di Tito. Napoli: ESI.

Magenta, N. 1984. Vocabolario del dialetto di Novi Ligure. Novi Ligure: Arti grafiche novesi.

Magri, R. 1995. Dialetto cremonese. 2 voll. Cremona: Edizioni Turris.

Mancarella, G. B. 1994. Lessico dialettale di Tursi. Lecce: Edizioni del Grifo.

Manzini, G. and Rocchi, L. 1995. Dizionario storico fraseologico etimologico del dialetto di Capodistria. (First edition 1989.) Rovigno/Trieste: Centro di ricerche storiche.

Massera, S. 1985. Vocabolario del dialetto di Novate Mezzola. Chiavenna: Centro di Studi Storici Valchiavennaschi.

Mattesini, E. and Uguccione, N. 1992. Vocabolario del dialetto del territorio orvietano. Perugia: Opera del vocabolario dialettale umbro.

Pagani, W. (ed.) 1983. Vocabolario del dialetto di Filattiera. I. Il corpo umano. Pisa: Pacini.

Pagani, W. (ed.) 1990. Vocabolario del dialetto di Filattiera. II. Lo spazio e il tempo. Pisa: Pacini.

Pagani, W. (ed.) 1997. Vocabolario del dialetto di Filattiera. III/1. La vegetazione e $i$ prodotti della terra. Pisa: Pacini.

Pellizzer, A. and Pellizzer, G. 1992. Vocabolario del dialetto di Rovigno d'Istria. 2 voll. Rovigno/Trieste: Centro di ricerche storiche.

Petracco Sicardi, G. (ed.) 1982. Vocabolario delle parlate liguri. Lessici speciali. 1. Gli uccelli. Genova: Sagep.

Piazzolla, S. 1982. Dizionario dialettale sanferdinandese. Trani: Vecchi.

Ravaro, F. 1994. Dizionario romanesco. Roma: Newton \& Compton.

Salzano, A. 1980. Vocabolario napoletano-italiano, italiano-napoletano. Napoli: Edizioni del Giglio.

Salvadori, G. B. 1999. Vocabolario del dialetto di Roncone. Comune di Roncone. 
Sella, A. 1992. Flora popolare biellese. Nomi dialettali, tradizioni e usi locali. Alessandria: Edizioni dell'Orso.

Sella, A. 1994. Bestiario popolare biellese. Nomi dialettali, tradizioni e usi locali. Alessandria: Edizioni dell'Orso.

Tempesta, F. and Valente, V. 1999. Vocabolario etimologico del dialetto di Terlizzi. Molfetta: Ed. Mezzina.

Tomasi, G. 1983. Dizionario del dialetto di Revine. Belluno: Istituto Bellunese di Ricerche Sociali e Culturali.

Tomasini, R. 1989. Il dialetto della Val Rendena. San Michele all'Adige: Museo degli usi e costumi della gente trentina.

Toso, F. 1998. Dizionario genovese. Milano: Vallardi.

Tropea, G. 1988. Lessico del dialetto di Pantelleria. Palermo: Centro di studi filologici e linguistici siciliani.

Vincelli, A. 1991. Vocabolario ragionato del dialetto di Casacalenda. Campobasso: Edizioni Enne.

Zaccagnini, R. 1992. Il Dialetto Velletrano. Velletri: Scorpius.

\section{B. Other literature}

Marello, C. 1989. 'Dizionario' in G. L. Beccaria (ed.) Dizionario di linguistica. Einaudi: Torino.

Marmo, V., Martinelli, M. and Mendia, L. 1981. 'Per una storia dell'ideologia dei Vocabolari Dialettali Italiani', in F. Albano Leoni and N. De Blasi (eds.) Lessico e semantica. Roma: Bulzoni, 423-452.

Pellegrini, G. B. 1977. Carta dei Dialetti d'Italia. Pisa: Pacini. 